\title{
EL DISCERNIMIENTO VOCACIONAL EN EL CAMINO DE CONVERSIÓN DE SAN FRANCISCO DE ASÍS.
}

DOI: https://doi.org/10.52039/seminarios.v55i193.470

Juan Miguel Vicente Valtueña, OfMConv

Fr. Juan Miguel Vicente Valtueña, nacido en 1960 en Puebla de Eca (Soria), es franciscano menor conventual, ha cursado estudios de especialización en el Pontificio Instituto Bíblico de Roma y actualmente es profesor de Sagrada Escritura en la Pontificia Facultad Teológica San Buenaventura (SERAPHICUM), en Roma.

En este trabajo encontramos un verdadero compendio de lo que podríamos llamar teología espiritual franciscana. El autor nos ha regalado una descripción de los hitos en el camino de conversión de san Francisco desde aquel primer encuentro en Espoleto hasta aquel en que san Francisco, a la hora de la muerte, pide le lean el texto del lavatorio. Pero este recorrido tiene una guía intencional. Se nos ofrece la descripción del discernimiento vocacional en la vida de san Francisco: el lugar preeminente y exclusivo del Evangelio en el caminar del santo; el encuentro y opción por los leprosos y pobres del mundo; la reparación de la Iglesia y para la Iglesia; el ímpetu misionero; la trayectoria mística. Los lectores habremos de sacar conclusiones para el discernimiento vocacional desde el estilo franciscano para todos en la Iglesia. 


\section{ÍNDICE}

1. El proceso de conversión de Francisco de Asís (42); a. La prisión en la cárcel de Perusa y la enfermedad posterior (44); b. El sueño del palacio lleno de armas y la visión de Espoleto (45); c. El encuentro con los pobres y la identificación con ellos (46); d. El beso al leproso (46); e. El encuentro con Cristo crucificado (47); f. El Evangelio de la misión (48); 2. La conversión de Francisco de Asís: ¿continuidad o ruptura entre el Testamento y las primeras biografías? (49); 3. El Evangelio, criterio de discernimiento en el itinerario existencial de Francisco de Asís (51); 4. La experiencia evangélica de Dios (54); 5. La experiencia evangélica del hermano (56); 6. La experiencia evangélica del mundo (58); Conclusión (60).

La figura de Francisco de Asís ha suscitado siempre en quienes se han acercado a él, a sus escritos, a su vida, un profundo sentimiento de admiración. Es un santo con el que resulta fácil sintonizar, a pesar de la distancia temporal, cultural e histórica que nos separa de él. El motivo de la fascinación que sigue suscitando la persona de Francisco es, sin duda alguna, su sencillez y frescura evangélicas, su transparencia, el modo concreto en que supo plasmar en su vida el estilo y los valores del Evangelio.

La celebración del octavo centenario de la conversión de San Francisco y de los orígenes del carisma franciscano (1209-2009) constituye una ocasión propicia para acercarnos una vez más al santo de Asís y reflexionar sobre su apasionante aventura evangélica. En las páginas que siguen vamos a ocuparnos de su largo y complejo proceso de conversión y de su posterior configuración a Cristo pobre y crucificado, itinerario que culmina, según los relatos de las fuentes hagiográficas, en la impresión de los estigmas, que Francisco recibe en el monte Alverna dos años antes de su muerte.

\section{El proceso de conversión de Francisco de Asís}

En el Testamento, el más personal y autobiográfico de sus escritos, Francisco de Asís, al término de su itinerario humano y espiritual, evoca los comienzos de su aventura evangélica, iniciada unos veinte años atrás, y resume su experiencia de conversión en unas pocas palabras, densas de sentido y significado: 
El Señor me dio a mí, el hermano Francisco, el comenzar de este modo a hacer penitencia: pues, como estaba en pecados, me parecía extremadamente amargo ver a los leprosos; pero el Señor mismo me llevó entre ellos, y practiqué con ellos la misericordia. Y, al separarme de ellos, lo que me parecía amargo se me convirtió en dulzura del alma y del cuerpo; $y$, después de un poco de tiempo, salí del mundo ${ }^{1}$.

En estas palabras Francisco subraya, en primer lugar, que su conversión no ha sido el resultado de sus esfuerzos y voluntad personales, sino fruto de la iniciativa divina. La irrupción de Dios en la vida de Francisco provoca un cambio de valores y actitudes, un nuevo modo de entender y orientar la vida: El Señor me dio... el comenzar de este modo a hacer penitencia... el Señor mismo me llevó entre ellos. Éste es el estribillo que Francisco repite una y otra vez en el Testamento, para evidenciar la acción constante de la gracia divina en él2. Todo ha sido don e iniciativa del Señor. La existencia entera del santo de Asís aparece, pues, como respuesta dócil a la iniciativa amorosa de Dios. Francisco considera don de Dios e inspiración divina no sólo la propia vocación, sino también la de sus hermanos, como aparece reflejado en la Primera regla o Regla no bulada de 1221: Si alguno viniera a nuestros hermanos queriendo, por divina inspiración, abrazar esta vida...3. Para Francisco, toda vocación nace de una inspiración divina.

1 Test 1-3. Uso aquí la traducción española de las fuentes franciscanas: San Francisco de Asís. Escritos. Biografías. Documentos de la época (edición preparada por J. A. GuerRA), Ed. BAC, Madrid 2003 ( $2^{a}$ ed., corregida y actualizada). Indico a continuación las abreviaturas de los escritos y biografías de S. Francisco citados en este artículo, siguiendo siempre los criterios de la edición mencionada:

a) Escritos de San Francisco [Adm: Admoniciones; AID: Alabanzas al Dios Altísimo; CtaM: Carta a un ministro; CtaO: Carta a toda la Orden; 2CtaF: Carta a los fieles (segunda redacción); 1R: Primera regla o Regla no bulada (1221); 2R: Segunda regla o Regla bulada (1223); Test: Testamento].

b) Fuentes biográficas [1C: TomÁs dE CELANo, Vida primera; 2C: TomÁs DE CELANo, Vida segunda; EP: Espejo de perfección; LM: SAN BUENAVENTURA, Leyenda mayor, LP: Leyenda de Perusa; TC: Leyenda de los tres compañeros].

2 El Señor me dio... el comenzar de este modo a hacer penitencia (Test 1); el Señor mismo me llevó entre ellos» (Test 2); "el Señor me dio una fe tal en las iglesias... (Test 4); el Señor me dio, y me sigue dando, tanta fe en los sacerdotes... (Test 6); el Señor me dio hermanos (Test 14); el mismo Altísimo me reveló que debía vivir según la forma del santo Evangelio (Test 14); el Señor me reveló que dijésemos este saludo: El Señor te dé la paz (Test 23); el Señor me dio decir y escribir sencilla y puramente la regla y estas palabras (Test 39).

$31 R 2,1$. 
Además, en el Testamento, Francisco señala que la experiencia de Dios incluye también una experiencia del hombre. La conversión a Dios, para que sea tal, conlleva necesariamente la conversión al hermano. Francisco lo expresa de manera muy gráfica y viva al hablar de su actitud ante los leprosos: la repugnancia que sentía hacia ellos se transformará, a la luz de su experiencia de Dios, en misericordia para con ellos. La auténtica experiencia de Dios proyecta, pues, una luz nueva sobre los demás. Son éstas las dos dimensiones -vertical y horizontal- de la conversión, que en el caso de Francisco aparecen perfectamente conjugadas y armonizadas.

En las fuentes hagiográficas, el relato de la conversión de Francisco está mucho más desarrollado, es una narración detallada del proceso lento y gradual que conducirá a la adhesión definitiva de Francisco a Cristo. En los relatos de su complejo itinerario vocacional, que dura unos cinco años (1205-1209), se destacan algunos episodios y momentos que revisten especial importancia y significado, en los cuales vamos a detenernos a continuación 4 .

\section{a. La prisión en la cárcel de Perusa y la enfermedad posterior}

Francisco, enrolado en el ejército de Asís para combatir contra la ciudad vecina de Perusa, cae prisionero en la batalla de Collestrada y pasa un año

4 Cf. P. B. Beguin, La conversión de Francisco a Cristo. Génesis de un encuentro, en Selecciones de Franciscanismo 14 (1985) 355-371; F. URIBE, El proceso vocacional de Francisco de Asís. Los seis encuentros que determinaron su vida, en Selecciones de Franciscanismo 30 (2001) 44-69; F. AccroccA, La conversione a Cristo di Francesco di Assisi, en AA.Vv, La conversione di San Francesco di Assisi. Una stimolante scelta di Cristo, Asís 2006, pp. 15-60; T. GÁlvez CAMpos, Francisco de Asís, paso a paso. Itinerario cronológico, geográfico y espiritual, Madrid 2009, pp. 37-80. Sin abordar aquí la compleja y debatida cuestión franciscana, es decir, las relaciones de interdependencia existentes entre las diversas fuentes hagiográficas, nos remitimos fundamentalmente a los testimonios que nos ofrecen la denominada Vida primera (Vita beati Francisci) de Tomás de Celano, escrita en 1228 con ocasión de la canonización de Francisco, y a la Leyenda de los tres compañeros (Legenda trium sociorum), que tiene su origen en la invitación dirigida en 1244 por el Capítulo general a todos los hermanos para que recogieran cuantos recuerdos existieran sobre la vida, las enseñanzas y los milagros del fundador. Tomás de Celano, al redactar la Vida segunda (Memoriale in desiderio animae de gestis et verbis sanctissimi Patris nostri Francisci: 1246-1247), se servirá del material recogido en la Leyenda de los tres compañeros, sobre todo para completar el relato de la juventud y conversión de Francisco, colmando lagunas y precisando algunos pormenores que no aparecían en la Vida primera. 
en la cárcel de Perusa ${ }^{5}$. Las penurias y tribulaciones de la prisión se prolongan con la larga enfermedad que sufre poco después de salir de la cárcel y regresar a Asís 6 . La prisión y la enfermedad, hacen notar los hagiógrafos, tendrán un efecto purificador en el ánimo de Francisco, cuestionando la vanidad, la frivolidad, la autosuficiencia y el afán de protagonismo mostrados hasta ese momento7. Tomás de Celano y el autor anónimo de la Leyenda de los tres compañeros usan el mismo verbo latino para describir el cambio interior que se estaba gestando en el joven Francisco: vilescere sibi (tenerse en menos a sí mismo). Es decir, Francisco comprende que se ha sobrevalorado, que su vanagloria y autosuficiencia no pueden seguir siendo el punto de referencia de su vida 8 .

\section{b. El sueño del palacio lleno de armas y la visión de Espoleto}

A pesar de haber sido marcado por la experiencia de la cárcel y la enfermedad, el joven Francisco sigue alimentando deseos de gloria y honores terrenos. Por eso interpreta el sueño del palacio lleno de armas como un buen augurio para su proyecto de convertirse en caballero, tal vez un gran príncipe ${ }^{9}$. Con esas intenciones, se alista en la expedición militar organizada por un noble de Asís para ir a combatir a la Pulla. Pero el Señor sale a su encuentro y, tras la visión de Espoleto, Francisco desiste de ir a la Pulla y regresa a su ciudad, dispuesto a buscar la voluntad de Dios y deseoso de conformarse a ella: Señor, ¿qué quieres que haga?10. En Espoleto Francisco abandona sus proyectos personales para abrazar el proyecto de Dios, aún por descubrir. Tomás de Celano, en la Vida segunda, paragonando la figura de Francisco a la Saulo camino de Damasco (Hch

$\begin{array}{lll}5 & T C & 4 . \\ 6 & 10 & 3 .\end{array}$

7 San Buenaventura lo explicita de un modo muy elocuente en la Leyenda mayor: Como quiera que el azote de la tribulación abre el entendimiento al oído espiritual, de pronto se hizo sentir sobre él la mano del Señor y la diestra del Altísimo operó en su espíritu un profundo cambio, afligiendo su cuerpo con prolijas enfermedades para disponer así su alma a la unción del Espíritu Santo (LM 1,2). Cf. F. CHAVERo BLANCO, 'Inmutatio dexterae Altissimi'. Lectura teológica de la conversión de San Francisco (Legenda maior, cap. 1), en Antonianum 75 (2000) 681-719.

8 1C 4: A partir de ese día, comenzó a tenerse en menos a sí mismo y a mirar con cierto desprecio cuanto antes había admirado y amado (cf. también TC 8). Cf. F. AccroccA, I "peccati" del giovane Francesco, en Frate Francesco 68 (2002) 203-204. 9 TC $5 ; 1 C 5 ; 2 C 6$.

10 TC $6 ; 2 C 6$. 
9,1-9), describe el episodio de Espoleto como el paso de la militia saeculi a la militia Dei, de la búsqueda de la gloria militar al deseo de los bienes eternos ${ }^{11}$.

\section{c. El encuentro con los pobres y la identificación con ellos}

La apertura de Francisco al proyecto y a la voluntad de Dios va acompañada también de la apertura a los demás, en especial a los pobres. Las fuentes hagiográficas describen a Francisco como un joven adornado con las virtudes naturales de la generosidad y la prodigalidad, que a veces derivaban en despilfarro y derroche ${ }^{12}$. En su proceso vocacional, Francisco transformará esa generosidad natural suya en auténtica sensibilidad evangélica ante la suerte de los pobres y desvalidos: Aunque ya de tiempo atrás era dadivoso con los pobres, desde entonces se propuso en su corazón no negar la limosna a ningún pobre que se la pidiese por amor de Dios, sino dársela con mayor liberalidad y abundancia de lo que acostumbraba ${ }^{13}$.

Con ocasión de una peregrinación a la tumba del apóstol Pedro en Roma, Francisco no se contenta con ser generoso con los pobres, sino que quiere experimentar también la condición de los mismos. Y así, vestido de andrajos, se une a los pobres que piden limosna en la escalinata de la iglesia $^{14}$.

\section{d. El beso al leproso}

Como ya hemos dicho, en el Testamento Francisco evoca su encuentro con los leprosos y su actitud para con ellos, y considera que dicha experiencia es la que mejor y más visiblemente expresa su proceso de conversión: de la repugnancia a la misericordia, de la amargura a la dulzura.

El conocido episodio del beso al leproso aparece recogido en todas las fuentes hagiográficas más antiguas, con algunas ligeras variantes ${ }^{15}$, pero

11 2C 6: Renunciando a la propia voluntad, de Saulo se convierte en Pablo... Cambia las armas carnales en espirituales, y recibe, en vez de la gloria de ser caballero, una investidura divina. Más adelante, Tomás de Celano denomina a Francisco "strenuus Christi miles" (2C 21). Cf. F. CARDINI, S. Francesco e il sogno delle armi, en Studi Francescani 77 (1980) 15-28; P. Messa, Francesco d'Assisi: dai sogni di grandezza alla grandezza di un sogno, en Frate Francesco 71 (2005) 57-89.

12 Cf. $1 C$ 2; TC 2-3.

13 TC 8.

14 Cf. TC 10.

15 Cf. $1 C$ 17; TC 11; 2C 9; LM 1,5. 
no desempeña en ellas la función relevante y central que Francisco le otorga en el Testamento. Para los biógrafos, el encuentro con el leproso constituye un paso más del joven Francisco en el dominio y la victoria sobre sí mismo: Mientras aún permanecía en el siglo, se topó cierto día con un leproso, y, superándose a sí mismo, se llegó a él y le dio un beso. Desde este momento comenzó a tenerse más y más en menos, hasta que, por la misericordia del Redentor, consiguió la total victoria sobre sí mismo'16. San Buenaventura, sin alejarse de esa línea interpretativa de los demás biógrafos, añade una lectura o motivación cristológica del encuentro de Francisco con los leprosos y su servicio solícito a éstos: a los ojos de Francisco, los leprosos se convierten en tipo y figura de Cristo crucificado, el cual, como dice la Escritura, apareció despreciable como un leproso (Is $53,3-4)^{17}$.

El encuentro de Francisco con el leproso no es un episodio aislado y anecdótico; el servicio a los leprosos se convertirá, en cambio, en una praxis habitual del santo a lo largo de toda su vida ${ }^{18}$. Y Francisco recomienda a sus hermanos que hagan lo mismo: $Y$ deben gozarse cuando conviven con gente baja y despreciada, con los pobres y débiles, con los enfermos y leprosos, y con los mendigos que están a la vera del camino ${ }^{19}$.

\section{e. El encuentro con Cristo crucificado}

Otro momento determinante en el proceso de conversión de Francisco es el

16 1C 17. La Leyenda de los tres compañeros presenta exactamente la misma interpretación de ese episodio: Yendo un día a caballo por las afueras de Asís, se cruzó en el camino con un leproso. Como el profundo horror por los leprosos era habitual en él, haciéndose una gran violencia, bajó del caballo, le dio una moneda y le besó la mano. Y, habiendo recibido del leproso el ósculo de paz, montó de nuevo a caballo y prosiguió su camino. Desde entonces empezó a despreciarse más y más, hasta conseguir, con la gracia de Dios, la victoria total sobre sí mismo (TC 11).

17 LM 1,6: Se revistió, a partir de este momento, del espíritu de pobreza, del sentimiento de la humildad y del afecto de una tierna compasión. Si antes, no ya el trato de los leprosos, sino el sólo mirarlos, aunque fuera de lejos, le estremecía de horror, ahora, por amor a Cristo crucificado, que, según la expresión del profeta, apareció despreciable como un leproso (Is 53,3-4), con el fin de despreciarse completamente a sí mismo, les prestaba con benéfica piedad a los leprosos sus humildes y humanitarios servicios.

18 Cf. $1 C$ 17; 39; 103; 2 C 66; TC 11-12; 55; LM 1,6; 2,6; $14,1$.

19 1R 9,2. Cf. F. DE AizPURÚA, Lo amargo, se me tornó en dulzura. La conversión del hermano Francisco como conversión social, en Selecciones de Franciscanismo 30 (2001) 180-192; F. URIBE, El proceso vocacional de Francisco de Asís... 53-56. 
que tiene lugar en la iglesia de San Damián: mientras ora ante la imagen del Crucificado, éste lo invita a reparar su casa, que amenaza ruina20. Francisco interpreta literalmente esas palabras y se dedica a restaurar la vetusta y deteriorada iglesia. Más tarde entenderá que ha sido llamado a reconstruir no el templo material, sino la comunidad de creyentes en Cristo crucificado y resucitado, la Iglesia.

El encuentro con el Crucificado marcará decisivamente la espiritualidad de Francisco, que a partir de entonces aspira a convertirse en seguidor fiel del Cristo siervo, pobre y crucificado, cuya existencia terrena comienza en el pesebre de Belén y termina en la cruz del Calvario, la máxima expresión de la "kénosis" o anonadamiento de aquel que, siendo el Señor de la majestad, ha querido hacerse hermano nuestro. Por eso los hagiógrafos, al referir el episodio del crucifijo de San Damián, aluden ya a la impresión de las llagas en el cuerpo de Francisco, un hecho que tendrá lugar al final de su vida21. Lo que sucedió en el monte Alverna en septiembre de 1224 no fue un hecho aislado e improvisado, sino algo que comenzó a gestarse en la iglesia de San Damián unos veinte años atrás, en el encuentro con el Crucificado. Es la gran "inclusión" que abraza y caracteriza la vida entera de Francisco: él, que fue un gran devoto de la pasión del Señor y un seguidor fiel del Cristo pobre y crucificado, al final de sus días recibió en su cuerpo los signos mismos de la pasión, que tanto había contemplado y meditado en su corazón 22 .

\section{f. El Evangelio de la misión}

El encuentro con Cristo crucificado en la iglesia de San Damián tiene su continuidad natural en el encuentro con el Evangelio, cuando Francisco escucha en la iglesia de Santa María de la Porciúncula el evangelio de la misión o envío de los apóstoles (Mt 10,5-15) y descubre en esas palabras lo que va a ser su programa de vida, el tesoro escondido y la perla preciosa que andaba buscando23.

20 Cf. TC 13; 2 C 10; LM 2,1.

21 TC 14-15: Desde aquel momento quedó su corazón llagado y derretido de amor ante el recuerdo de la pasión del Señor Jesús, de modo que mientras vivió llevó en su corazón las llagas del Señor Jesús, como después apareció con toda claridad en la renovación de las mismas llagas admirablemente impresas en su cuerpo y comprobadas con absoluta certeza... Desde la visión y alocución de la imagen del crucifijo, fue hasta su muerte imitador de la pasión de Cristo (cf. también 2 C 10-11).

22 Cf. F. URIBE, El proceso vocacional de Francisco de Asís... 58-59.

23 1C 22: Cierto día se leía en esta iglesia el evangelio que narra cómo el Señor había 
Tomás de Celano indica que Francisco se encontraba entonces en el tercer año de su conversión. El proceso de búsqueda iniciado tres años atrás por aquel joven que aspiraba a convertirse en caballero, búsqueda plasmada claramente en la pregunta de la visión de Espoleto, Señor, ¿qué quieres que haga?24, estaba llegando a su término: Esto es lo que yo quiero, esto es lo que yo busco, esto es lo que en lo más íntimo del corazón anhelo poner en práctica ${ }^{25}$. La misión que le había sido confiada en la iglesia de San Damián, Francisco, ¿no ves que mi casa se derrumba? Anda, pues, y repárala ${ }^{26}$ es iluminada ahora con una luz nueva; el Evangelio se convierte en criterio fundamental de discernimiento e ilumina de manera definitiva el futuro de Francisco. El anuncio de la Buena Noticia del Reino y de la conversión que éste requiere es el único camino para reconstruir la Iglesia.

La misión se convierte así en componente esencial de la vocación de Francisco, una misión desarrollada con el estilo y las actitudes que Jesús pide a los suyos en el Evangelio: desprovistos de todo, inermes, libres; sólo con la sencillez y la autenticidad del testimonio. Esas instrucciones evangélicas serán incluidas más tarde en la Regla de la fraternidad franciscana27: los hermanos menores, como los apóstoles enviados por Jesucristo, han de anunciar el Evangelio con libertad, sin someterse a nada ni a nadie que pueda amordazar la fuerza de la Palabra, desprendiéndose de todo aquello que pueda oscurecer o entorpecer su testimonio, de tal manera que la Buena Nueva se manifieste con todo su brillo y esplendor.

\section{La conversión de Francisco de Asís: ¿continuidad o ruptura entre el Testamento y las primeras biografías?}

enviado a sus discípulos a predicar; presente allí el santo de Dios, no comprendió perfectamente las palabras evangélicas; terminada la misa, pidió humildemente al sacerdote que le explicase el evangelio. Como el sacerdote le fuese explicando todo ordenadamente, al oír Francisco que los discípulos de Cristo no debían poseer ni oro, ni plata, ni dinero; ni llevar para el camino alforja, ni bolsa, ni pan, ni bastón; ni tener calzado, ni dos túnicas, sino predicar el reino de Dios y la penitencia, al instante, saltando de gozo, lleno del Espíritu del Señor, exclamó: "Esto es lo que yo quiero, esto es lo que yo busco, esto es lo que en lo más íntimo del corazón anhelo poner en práctica" (cf. también TC 25; LM 3,1).

24 TC 6; 2C 6; LM 1,3.

$251 C 22$.

26 TC 13; 2 C 10; LM 2,1.

27 Cf. $1 R$ 14; $2 R$ 3,10-14. 
En un estudio reciente, después de haber analizado minuciosamente la breve síntesis de la experiencia de conversión que Francisco nos ha dejado en su Testamento y los relatos mucho más amplios y detallados de las primeras biografías del santo, Pietro Maranesi se pregunta si hay continuidad y desarrollo entre el breve relato autobiográfico y las narraciones de las biografías, o bien tenemos que hablar de ruptura y contraste 28 .

La experiencia de conversión vivida por Francisco, tal como él la resume en las primeras líneas del Testamento, ha seguido un camino descendente: al encontrarse con los leprosos, despreciados y excluidos, los últimos en la sociedad de aquella época, al compartir su condición y practicar la misericordia para con ellos, Francisco ha descubierto también el misterio de Dios, Aquel que, siendo el Altísimo, por amor se ha abajado para compartir nuestra condición humana y nuestra historia, hasta morir excluido y despreciado en la cruz.

En cambio, según los relatos de las primeras biografías, la experiencia de Dios vivida por Francisco parece seguir otros derroteros, un camino que podemos definir ascendente: aquí el acontecimiento decisivo en su proceso de conversión no es el encuentro con la marginación escandalosa de los leprosos, sino la experiencia excepcional, mística, vivida ante la cruz de San Damián. El itinerario recorrido por Francisco hasta entonces, del cual forma parte también el encuentro con los pobres y los leprosos, es presentado como un proceso lento y gradual de purificación de los deseos de la carne, un camino ascético de dominio y victoria sobre sí mismo, una preparación adecuada y necesaria para poder encontrarse con Dios, que por fin irrumpe en su vida y le manifiesta su voluntad 29 .

En realidad, concluye Maranesi, la experiencia de servicio misericordioso a los leprosos (Testamento) y la experiencia mística ante el crucifijo de San Damián (biografías) no son verdades o relatos enfrentados, sino teológicamente complementarios. Por una parte, la misericordia para con los leprosos constituye el inicio y el requisito de lo que sucederá luego en San Damián; y por otra, el encuentro místico con el misterio de Cristo crucificado ilumina con una luz nueva y definitiva el encuentro con los leprosos. Una experiencia remite a la otra, y ambas se iluminan mutuamente. El servicio a los leprosos conduce a Francisco al encuentro con Cristo; el Crucificado de la imagen de San Damián puede hablarle

28 P. MARANESI, "Facere misericordiam". La conversione di Francesco d'Assisi: confronto critico tra il Testamento e le Biografie, Asís 2007, p. 289.

29 Ibid., pp. 289-290. 
porque Francisco había descubierto y experimentado ya el misterio del sufrimiento en el rostro y la carne de los leprosos. Al mismo tiempo, la pasión del Crucificado proyectará una luz nueva sobre la pobreza crucificada de los leprosos. En definitiva, Francisco encuentra a Cristo en los leprosos y a los leprosos en Cristo. Y en la experiencia existencial y mística de ese encuentro Francisco descubre su programa de vida: la misericordia, que es renuncia a todo tipo de poder, dominio, pretensión o posesión, para ser menor entre los menores de la sociedad 30.

\section{El Evangelio, criterio de discernimiento en el itinerario existencial de Francisco de Asís}

Como ya hemos apuntado antes, el Evangelio constituye el criterio fundamental de discernimiento no sólo en el proceso de conversión de Francisco, sino también a lo largo de toda su existencia posterior. La Escritura en general y el Evangelio en particular ocupan un lugar central en la experiencia e itinerario espiritual de Francisco. Su espiritualidad es profundamente bíblica: la oración, la predicación, el lenguaje, la vida entera de Francisco, en definitiva, se nutren de la Escritura, fuente inagotable de inspiración para él. Es suficiente una lectura -incluso superficial- de los escritos de Francisco para constatar el talante bíblico de los mismos; la presencia de la Escritura es constante en ellos: las oraciones compuestas por Francisco, sus cartas, la Primera regla o Regla no bulada, son un mosaico de citas bíblicas; el mismo lenguaje y las imágenes empleadas por Francisco poseen un sabor y un tono inequívocamente bíblicos.

Francisco parece sentir una predilección especial por determinados textos evangélicos, que aparecen citados con insistente reiteración en sus escritos: el sermón del monte (Mt 5-7), que revela a Francisco el gozo y la bienaventuranza del Reino, de la paternidad de Dios, y le muestra al mismo tiempo el camino de la desapropiación y la cruz para acceder al Reino; el evangelio de la misión de los apóstoles (Mt 10,5-15; Lc 9,1-6; 10,1-12); los pasajes evangélicos en los que Jesús expone las condiciones del seguimiento (Mt 16,24-26; 19,21.29; Mc 10,29; Lc 14,25-27); la denominada oración sacerdotal de Jesús (Jn 17); el episodio del lavatorio de los pies (Jn 13,1-16), donde el Maestro aparece a los ojos de Francisco como modelo excelso de minoridad y servicio ${ }^{31}$.

30 Ibid., pp. 294-296.

31 Cf. O. VAN AsseldonK, Insegnamenti biblici privilegiati negli scritti di San Francesco, en AA.VV., Lettura biblico-teologica delle fonti francescane, Roma 1978, pp. 83-116; F. 
La Palabra de Dios marca el inicio y el final de la aventura evangélica de Francisco. En el proceso de su conversión, la escucha del evangelio de la misión de los apóstoles (Mt 10,5-15) constituirá un momento decisivo. Francisco descubre en ese pasaje bíblico el tesoro escondido, la perla preciosa, la forma de vida que él estaba buscando: Esto es lo que yo quiero, esto es lo que yo busco, esto es lo que en lo más íntimo del corazón anhelo poner en práctica32. Y al final de su camino, cuando Francisco se prepara para recibir a la hermana muerte orando con las palabras del Sal 141, pide que le lean una vez más el texto de Jn 1333. La Escritura será compañera inseparable de Francisco a lo largo de toda su vida, no sólo en esos instantes inicial y final. A la hora de tomar decisiones importantes, él recurre siempre a la Palabra de Dios, criterio de discernimiento insustituible, como escribe en el Testamento: Nadie me mostraba qué debía hacer, sino que el mismo Altísimo me reveló que debía vivir según la forma del santo Evangelio ${ }^{34}$. Efectivamente, el Evangelio es la única forma de vida que Francisco desea para sí y para los suyos, tal como aparece al comienzo de la Regla: La regla y vida de los Hermanos Menores es ésta: observar el santo Evangelio de nuestro Señor Jesucristo... 35 .

Cuando Francisco se presenta con sus primeros hermanos ante el Papa Inocencio III para solicitar la aprobación de su forma de vida, el cardenal Juan de San Pablo, refiere Tomás de Celano, le aconseja que se oriente hacia la vida monástica o eremítica, es decir, hacia aquellas formas de vida religiosa que ya existían en la Iglesia de la época. Pero Francisco no ceja en su empeño, no por desprecio de lo que se le propone, sino porque se siente llamado a otro ideal y otro tipo de vida, consciente de la riqueza y la novedad perenne del Evangelio ${ }^{36}$.

Francisco se siente y se define indocto ${ }^{37}$, pero esto no constituye un obstáculo insuperable para que manifieste al mismo tiempo una profunda comprensión y asimilación de la Escritura, porque su aproximación a ella, como señala hermosamente Tomás de Celano, se realiza no a través de la ciencia del maestro, sino por medio del afecto y la pasión del amante ${ }^{38}$.

\footnotetext{
$321 \mathrm{C} 22$.

33 Cf. 1 C 109-110.

34 Test 14.

$352 R$ 1,1; cf. $1 R$ pról 2.

36 Cf. $1 C$ 32-33. En $1 C 82$ Tomás de Celano presenta a Francisco como «hombre nuevo». Cf. F. AccroccA, La conversione a Cristo di Francesco di Assisi..., pp. 36-37. 37 Test 19: Y éramos indoctos y estábamos sometidos a todos.

38 2C 102: Aunque este hombre bienaventurado no había hecho estudios científicos,
} 
Francisco vibra en sintonía cordial y comunión profunda con la Escritura, revelación del amor del Padre, manifestado de modo particular en Cristo pobre y crucificado, síntesis y compendio de toda la Escritura39. Es el Espíritu del Señor, que actúa en nosotros, dirá Francisco, el que nos permite captar esa verdad salvadora 40 . El santo de Asís posee, pues, un conocimiento sapiencial y existencial de la Escritura, un conocimiento que ha madurado en la relación personal e íntima con el Dios que en ella se nos revela.

Esa concepción de la Escritura hace que Francisco manifieste hacia ella el mismo amor, respeto y veneración que muestra para con la Eucaristía: $Y$ quiero que estos santísimos misterios (Eucaristía) sean honrados y venerados por encima de todo y colocados en lugares dignos. $Y$ dondequiera que encuentre en lugares indebidos los santísimos nombres del Señor y sus palabras escritas, quiero recogerlos, y ruego que se recojan y se coloquen en lugar decoroso ${ }^{41}$. Este paralelismo entre Eucaristía y Palabra de Dios que hallamos en los escritos y en la espiritualidad de Francisco remite a la tradición de los Padres de la Iglesia y ha sido recordado y subrayado también por el Concilio Vaticano II en la Dei Verbum ${ }^{42}$. La honda estima de Francisco hacia la Escritura se extiende igualmente a todos aquellos que se dedican a profundizar en la comprensión de la misma, es decir, los teólogos, quienes a través de su ministerio dispensan espíritu y vida. Ese aprecio lo expresa Francisco en la Carta al hermano Antonio y en el Testamento: Debemos también honrar y venerar a todos los teólogos y a los que nos administran las santísimas palabras divinas, como a quienes nos administran espíritu y vida ${ }^{43}$.

con todo, aprendiendo de Dios la sabiduría que viene de lo alto e ilustrado con las iluminaciones de la luz eterna, poseía un sentido no vulgar de las Escrituras. Efectivamente, su ingenio, limpio de toda mancha, penetraba hasta lo escondido de los misterios, y su afecto de amante entraba donde la ciencia de los maestros no llegaba a entrar. Leía a veces los libros sagrados, y lo que confiaba una vez al alma le quedaba grabado de manera indeleble en el corazón. La memoria suplía a los libros; que no en vano lo que una vez captaba el oído, el amor lo rumiaba con devoción incesante. Decía que le resultaba fructuoso este método de aprender y de leer y no el de divagar entre un millar de tratados.

39 Cf. $2 C 105$.

40 Cf. Adm 7.

41 Test 11-12; cf. también CtaO 34-37.

42 DV 21: La Iglesia siempre ha venerado la Sagrada Escritura, como lo ha hecho con el Cuerpo de Cristo, pues sobre todo en la sagrada liturgia, nunca ha cesado de tomar y repartir a sus fieles el pan de vida que ofrece la mesa de la Palabra de Dios y del Cuerpo de Cristo.

43 Test 13. 
Desde el momento de su conversión, la existencia de Francisco se transforma en un camino gradual y constante de configuración a Cristo, y en ese camino el Evangelio es siempre brújula y faro ${ }^{44}$. En el relato de los hagiógrafos, el seguimiento de Cristo pobre y crucificado por parte de Francisco y su identificación con él culminan en la impresión de las llagas en el cuerpo del santo. Dado que éste lleva hondamente arraigada en el corazón la cruz de Cristo, los signos de la pasión se imprimen también en su carne. Los estigmas de la pasión se convierten así en el signo visible de la plena adhesión a Cristo y la perfecta sintonía de actitudes y sentimientos con el Maestro45. Como dice San Buenaventura, los estigmas hacen de Francisco la imagen visible de Cristo crucificado; el amante es transformado en la imagen misma del amado46.

En ese proceso de configuración a Cristo, el Evangelio determinará asimismo el modo en que Francisco concibe y vive su relación con Dios, con los demás y con el mundo, relaciones que vamos a considerar a continuación.

\section{La experiencia evangélica de Dios}

Desde los inicios de su conversión, cuando se dirige a Dios pidiéndole Señor, ¿qué quieres que haga?47, hasta los últimos instantes de su vida, en los que se exhorta a sí mismo e invita a sus hermanos a nuevos comienzos, comencemos, hermanos, a servir al Señor nuestro Dios, pues bien poco es lo que hasta ahora hemos progresado48, toda la existencia de

\footnotetext{
44 1C 84: La suprema aspiración de Francisco, su más vivo deseo y su más elevado propósito, era observar en todo y siempre el santo Evangelio y seguir la doctrina de nuestro Señor Jesucristo y sus pasos con suma atención, con todo cuidado, con todo el anhelo de su mente, con todo el fervor de su corazón. En asidua meditación recordaba sus palabras y con agudísima consideración repasaba sus obras. Tenía tan presente en su memoria la humildad de la encarnación y la caridad de la pasión, que difícilmente quería pensar en otra cosa.

45 1C 115: Porque con ardoroso amor llevaba y conservaba siempre en su corazón a Jesucristo, y éste crucificado, fue señalado gloriosísimamente sobre todos con el sello de Cristo; 2C 211: Francisco estaba ya muerto al mundo y Cristo vivía en él. Los placeres del mundo le eran cruz, porque llevaba arraigada en el corazón la cruz de Cristo, y por eso le brillaban las llagas al exterior, en la carne, porque la cruz había echado muy hondas raíces dentro, en el alma.

46 Cf. $L M 13,3$.

47 TC 6.

48 LM 14,1.
} 
Francisco estuvo orientada a una búsqueda ininterrumpida de Dios.

El Dios de Francisco no es el resultado de una especulación ni de una teología. Es el Dios revelado en su vida, sentido como fuerza salvadora, luz, vida, amor, una realidad inédita y siempre atrayente. Las Alabanzas al Dios Altísimo son seguramente el texto de los escritos que mejor expresa quién es Dios para Francisco. Los atributos que ahí se aplican a Dios, y que se repiten en otros escritos suyos, dicen claramente quién es Dios para Francisco: presencia, fuerza, don, liberación, misterio, gozo, amor... Dios es todo bien, el sumo bien 49 , Aquel en el que se concentra toda la atención, todas las aspiraciones, todo sentimiento. En Dios se da todo lo que es deseable, toda la riqueza que el hombre puede anhelar. Para Francisco, Dios no es, pues, algo terrible ni temible, sino amable y deseable; no es una realidad lejana y distante, sino cercana, íntima y vinculante; no es una definición escolástica, sino una experiencia singular. Dios será para Francisco su razón de ser, su anhelo, su meta, su fiesta. Cuando repetía como una letanía Dios mío y todas mis cosas, estaba expresando el lugar que Dios ocupaba en su vida.

A la luz de Dios, el hombre aparece en sus justas proporciones. ¿Quién eres Tú, Dios mío?, preguntaba Francisco al Altísimo, e inmediatamente añadía la pregunta sobre sí mismo: ¿Y quién soy yo?50. El Tú al que se dirige Francisco no es un Dios que hunde y confunde al hombre; es el Dios creador, salvador y misericordioso, que crea, redime, eleva y humaniza al hombre. Dios no es el rival y el gran obstáculo del ser humano.

La oración continua de Francisco tiene su fundamento en esa certeza de que Dios es el sumo bien, todo bien. $Y$ desde ese reconocimiento su vida entera se transforma en alabanza, adoración, canto y diálogo. La oración de Francisco es expresión de un hombre reconciliado, liberado y vinculado existencialmente. Francisco va a Dios no sólo por la oración litúrgica de la Iglesia, sino también a través de toda la creación. Él fue genial en la oración porque fue genial en descubrir a Dios en todas las dimensiones de la vida. Dios es para él la realidad fundante, vivificante y, por tanto, presente en todo y en todos.

Francisco tenía un gran sentido de la distancia existente entre Dios y el hombre, todos nosotros, míseros y pecadores, no somos dignos de nombrarte ${ }^{51}$, porque había comprendido la inmensidad de Dios Uno y Trino.

49 AID 3.

50 Consideraciones sobre las llagas, $3^{\mathrm{a}}$ consideración.

$511 R 23,5$. 
Pero, a su vez, había experimentado también que ese Dios trascendente se ha hecho presencia cercana a través de Jesucristo, en el misterio de la encarnación: en Jesús, el Señor de la majestad se ha hecho hermano nuestro; el Altísimo se ha abajado para ponerse a nuestra altura; el Señor se ha hecho siervo; el Omnipotente se ha hecho débil e inerme. Y la actitud más adecuada del hombre ante ese misterio es el reconocimiento agradecido, la alabanza sincera, el canto exultante 52.

La experiencia religiosa de Francisco nos descubre, en definitiva, todo un mundo de relaciones vividas y profundizadas. Francisco busca a Dios en su intimidad, en la soledad; lo busca en el grupo fraterno, en la Iglesia, en la liturgia, en la sociedad, en la naturaleza y en cualquier acontecimiento. En todos esos espacios encuentra a Dios, porque los vive en profundidad y percibe en ellos la raíz última que remite a Dios. Francisco se siente irresistiblemente atraído y habitado por Dios, que es quien da el más profundo sentido a su persona, su vida y sus aspiraciones. Ese Dios buscado y amado es la raíz de su mirada para comprender la existencia, vivir con los otros, descubrir el misterio de la naturaleza y ver el sentido de la historia. Francisco es un gran especialista de Dios y un testigo excepcional de la presencia divina en el hombre y en el mundo.

\section{La experiencia evangélica del hermano}

Francisco amó tan intensamente a Dios que a partir de ese amor pudo amar también a los hombres, y tanto amó a los hombres que a partir de ese amor se afianzó más en Dios.

La imagen de Dios que Francisco tiene continuamente ante sí es profundamente evangélica: Dios será siempre para él el Padre que Jesús nos ha revelado. Dios creador, que ha hecho al hombre a su imagen y semejanza, en su Hijo Jesucristo nos ha hecho a todos también hijos suyos. Para Francisco, por tanto, los hermanos son tales porque son, ante todo, hijos de un mismo Padre. Sólo quien se sabe y experimenta hijo de un Padre común es capaz de aceptar al otro como hermano. Precisamente por ello, en el Testamento, Francisco reconoce y acoge a los hermanos de la fraternidad naciente como una verdadera gracia y regalo de Dios: El Señor me dio hermanos ${ }^{53}$. Cada uno de los hermanos es aceptado en la

52 Cf. Adm 1,16-18; 2 CtaF 4-5; CtaO 27-29.

53 Test 14. 
fraternidad como un don, tal como es, con sus virtudes y defectos.

Uno de los rasgos más característicos y humanos de Francisco es el profundo respeto por el otro y por su propia sensibilidad, que siempre trató de proteger y estimular. Él no tenía un esquema ya hecho y prefabricado de cómo debiera ser el auténtico hermano menor; no ofrece a quienes se acercan a él un molde y una imagen a los que necesariamente todos han de acomodarse. Él observa mucho a todos y a cada uno, y en todos y en cada uno descubre una dimensión y unos rasgos del verdadero hermano menor, del que jamás quiso ponerse como modelo y espejo. Fruto de esa mirada atenta y amorosa es la descripción del verdadero hermano menor que encontramos en el Espejo de perfección: para Francisco, la perfección no es una lista de virtudes abstractas, sino una serie de personas concretas que encarnan algunas de las muchas virtudes que ningún individuo concreto puede acaparar; es la síntesis y comunión de muchas existencias, una realidad siempre por hacer 54 .

Francisco sabe captar lo mejor que hay en cada uno de aquellos con los que convive y lo propone como riqueza para todos. En la fraternidad cada miembro es portador de una riqueza que nadie puede suplir. Como dice José Antonio Merino en una acertada formulación, en la fraternidad franciscana ningún hermano debe ser más que el otro, pero todos serán menos sin el otro55.

Francisco antepone las exigencias de la caridad fraterna al rigor de la penitencia; para él el hermano es más importante que cualquier sacrificio o práctica penitencial. Así, cuando un hermano se queja en mitad de la noche abrumado por el hambre, Francisco manda preparar la mesa y dispone que todos se sienten a comer, para que ese hermano no se avergüence de comer solo56. En otra ocasión, acompaña a un hermano débil y enfermo a una viña y, sentados los dos junto a una vid, Francisco empieza a comer uvas para que el hermano no se avergüence de comérselas solo57.

En la Carta a los fieles, Francisco se presenta como el hermano Francisco, el siervo, el súbdito, el que está a los pies de todos 58 . Ha puesto toda su vida al servicio de los demás de un modo incondicional, y pide la misma actitud a los suyos. Francisco exige que ninguno de los hermanos tenga

54 Cf. EP 85.

55 J. A. Merino, Humanismo franciscano. Franciscanismo y mundo actual, Madrid 1982, p. 167.

$56 \angle P 50$.

$57 \angle P 53$.

58 CtaF 1-2. 
potestad o dominio entre ellos, que se sirvan y se obedezcan: $Y$ a ninguno se le llame prior, sino que a todos sin excepción se les llame hermanos menores. Y lávense los pies los unos a los otros 59 .

Otro texto de los escritos que refleja la extraordinaria sensibilidad humana y la exquisita calidad espiritual de Francisco es la Carta a un ministro. hermano pecador que se presenta ante el ministro no es un súbdito al que hay que reprocharle su pecado, sino un hermano que debe ser acogido y amado. Sólo este amor, y no los reproches ni las condenas, puede llegar a tocar el corazón del hermano y hacer así posible el perdón y la transformación 60 .

\section{La experiencia evangélica del mundo}

Francisco acoge con sentimientos de hermandad no sólo a los seres humanos, sino también a la naturaleza entera, a todos los seres de la creación, que comparten con el hombre una misma condición: ser criaturas del mismo y único Creador. El Cántico de las criaturas es la expresión más sublime de esos sentimientos fraternos de Francisco. Desligado de esa profunda raíz y experiencia de fe, el amor de Francisco a la naturaleza sería mero ecologismo. Para Francisco toda criatura merece y debe ser no sólo respetada, sino también admirada, contemplada y amada, porque es reflejo, huella y sacramento del Dios creador y Padre de todo y de todos.

Como dice Tomás de Celano, tenía tal respeto a la naturaleza y a todo lo que hay en ella que en las criaturas sabía reconocer la mano del Creador, y en la belleza del universo la gloria y la hermosura de su Autor61. En

$591 R$ 6,3-4.

60 CtaM 9-11: Y en esto quiero conocer si amas al Señor y me amas a mí, siervo suyo y tuyo, si procedes así: que no haya en el mundo ningún hermano que, habiendo pecado todo lo que pudiera pecar, se aleje jamás de ti, después de haber visto tus ojos, sin tu misericordia, si es que busca misericordia. $Y$, si no buscara misericordia, pregúntale tú si quiere misericordia. Y, si mil veces volviera a pecar ante tus propios ojos, ámalo más que a mí, para atraerlo al Señor; y ten siempre misericordia de los tales.

$612 C$ 165: En una obra cualquiera canta al Artífice de todas; cuanto descubre en las hechuras, lo refiere al Hacedor. Se goza en todas las obras de las manos del Señor, y a través de tantos espectáculos de encanto intuye la razón y la causa que les da vida. En las hermosas reconoce al Hermosísimo; cuanto hay de bueno le grita: "El que nos ha hecho es el mejor". Por las huellas impresas en las cosas sigue dondequiera al Amado, hace con todas una escala por la que sube hasta el trono. Cf. también LM 9,1 . 
Francisco la naturaleza jamás es objeto útil ni campo permitido para desarrollar la ambición incontrolada del hombre. La mirada de Francisco sobre las cosas nunca fue interesada y su voluntad quedó libre de la codicia y de todo deseo de posesión y dominio. Francisco trata las cosas con inmensa simpatía y cordialidad, pues sabe que el hombre no es amo y señor de la creación, sino administrador responsable de la misma, que le ha sido confiada por Dios.

Así, pues, si Dios está en el fondo de la creación y de la vida, ¿cómo va a ser posible no amar al mundo y a los seres que hay en él? El medievalista francés Jacques Le Goff, que ha dedicado también diversos artículos y ensayos a la figura de Francisco de Asís, señala que la fascinación que suscitó y sigue suscitando San Francisco depende fundamentalmente de dos factores: el realismo y el gozo que caracterizan a Francisco y que hallan su expresión más sublime en el Cántico de las criaturas. Ese amor al mundo creado, dice Le Goff, coloca a Francisco en una perspectiva radicalmente distinta del filón de la mística medieval que ponía en el centro el denominado contemptus mundi (rechazo y desprecio del mundo). Si el mundo es obra de Dios, ¿cómo va a ser despreciable?, enseña Francisco62.

Cuando el pensamiento de la llustración y la modernidad proclame el olvido de Dios para atender a la tierra y ser fieles a la misma, olvidará que el auténtico cristianismo, como atestigua Francisco con su vida, es humanización del mundo y respeto por todo lo creado. Para Francisco, Dios jamás es motivo de ceguera que impida ver los valores humanos y mundanos. Pocos como Francisco y los suyos gozaron de una mirada tan transparente y tan fraternal, y por eso simpatizaron de un modo profundo con todos los seres de la creación, hasta llegar a aplicar el entrañable vocablo de hermano y hermana" a todas las criaturas. El corazón de Francisco vibró siempre con una enorme pasión por la vida, lo amó todo y gozó con todo, sin retener nada ni apropiarse de nada.

Para Francisco, pues, Dios jamás hipoteca al hombre y al mundo, lo eterno no ensombrece lo temporal, lo infinito no absorbe lo finito, lo absoluto no devora lo relativo, el más allá no es olvido y abandono del más acá. Todo lo contrario: Dios es el gran motivo para amar al hombre y amar el mundo, para comprometerse en la humanización y transformación de los mismos.

62 Cf. J. Le Goff, San Francesco d'Assisi, Roma-Bari 2000, pp. 63-73. 


\section{Conclusión}

Desde los inicios de su conversión hasta el final de su vida, Francisco de Asís se mostró oyente atento del Evangelio y solícito ejecutor de la voluntad del Señor que se revela en él63. A la luz del Evangelio tejió su relación con Dios, con los demás y con el mundo, convirtiéndose en constructor de fraternidad y comunión en la sociedad y la Iglesia de su época, donde eran muchas las cosas que amenazaban ruina y necesitaban ser reconstruidas o rejuvenecidas. Y a la luz del Evangelio vivió su itinerario de paulatina configuración a su Señor y Maestro, el Cristo siervo, pobre y crucificado.

$631 \mathrm{C}$ 22: Nunca fue oyente sordo del Evangelio sino que, confiando a su feliz memoria cuanto oía, procuraba cumplirlo a la letra sin tardanza. 